\title{
Indonesian Demand for Online Shopping: Revisited
}

\author{
Syarifudin Yahya ${ }^{1}$ and Catur Sugiyanto ${ }^{2 *}$ \\ ${ }^{1}$ BPS Staf, Jl Dr Sutomo nà 5-8, Pasar Baru, Kec. Sawah Besar, Kota Jakarta Pusat, DKI, 10710, \\ Indonesia (MEP UGM alumni, BPS 3) \\ ${ }^{2}$ Department of Economics, Faculty of Economics and Business, Universitas Gadjah Mada, \\ Yogyakarta, 55281, Indonesia
}

\begin{tabular}{|c|c|}
\hline ABSTRACT & ARTICLE INFO \\
\hline $\begin{array}{l}\text { Introduction/Main Objectives: This study aims to analyze the factors } \\
\text { that influence online shopping. Data are aggregated at the national, } \\
\text { island, and regional levels. The regions are categorized based on their } \\
\text { level of demand for online shopping. Background Problems: The rapid } \\
\text { development of information and communications technology contributes } \\
\text { to the transformation of the digital economy. By using 281,185 internet } \\
\text { users from the National Households Survey (Survei Sosial Ekonomi- } \\
\text { Susenas) } 2017 \text { data, we found that the percentage of online shopping in } \\
\text { Indonesia is } 7.59 \% \text {. Online shopping is concentrated on the island of } \\
\text { Java, especially in the Greater Jakarta area (Jakarta, Bogor, Depok, } \\
\text { Tangerang, and Bekasi). Novelty: This study analyzes online shopping } \\
\text { from the point of view of economic development studies, especially } \\
\text { related to the development of information technology and the digital } \\
\text { economy. Research Methods: We used a binary logistic regression } \\
\text { analysis to assess the effect of demographic, socio-economic, and spatial } \\
\text { factors on an individual's decision to shop online. Finding/Results: The } \\
\text { results indicate that individuals who have a greater tendency to shop } \\
\text { online are those who have a high income, are women, can access the } \\
\text { internet using mobile phones, they are the spouses of the heads of } \\
\text { households, are } 25 \text { to30 years old, live in urban areas, have graduated } \\
\text { from college (especially with a diploma), and work in the tertiary sector. } \\
\text { The higher that the share of online shopping is in an area, the more } \\
\text { intense the influence of individual characteristics will be on the tendency } \\
\text { to shop online, according to the demographic and socio-economic factors, } \\
\text { while the spatial factors will fade away. Conclusion: Income, gender, } \\
\text { internet access, and the shopper's position in the household are factors } \\
\text { that significantly influence individuals to shop online. }\end{array}$ & $\begin{array}{l}\text { Article information: } \\
\text { Received in } 12 \text { April } \\
2020 . \\
\text { Received in revised form } \\
\text { 2 July } 2020 . \\
\text { Received in revised form } \\
\text { 15 July } 2020 . \\
\text { Accepted } 23 \text { July } 2020 .\end{array}$ \\
\hline
\end{tabular}

\footnotetext{
${ }^{*}$ Corresponding Author at Department of Economics, Faculty of Economics and Business, Universitas Gadjah Mada, Yogyakarta, 55281, Indonesia.

E-mail address:catur@ugm.ac.id
} 


\section{INTRODUCTION}

Information and communication technology (ICT) in Indonesia has developed so rapidly. A survey conducted by the Indonesian Internet Service Providers Association (APJII) found that the number of internet users in Indonesia in 2017 reached 143.26 million, increasing by $8 \%$ from the previous year (APJII, 2017). In line with the rapid growth of internet users, the growth in the use of smartphones in Indonesia has also increased. Smartphone users in Indonesia in 2017 amounted to 105.6 million(Das et al., 2018). This condition directly or indirectly will bring changes in their life patterns for people in Indonesia.

The rapid development of ICT has caused changes in people's behavior, in almost all their activities. Indonesia's large population was estimated at around 261 million in 2017 (BPS, 2018) making Indonesia a potential market for online shopping. The 2016 Economic Census shows that, within 10 years, the number of ecommerce outlets in Indonesia rose by around $17 \%$ to 1.37 million businesses or $5.15 \%$ of the total number of businesses (BPS, 2017a). Das et al (2018) estimated a market in Indonesia comprising about $\$ 5$ billion of formal e-tailing and more than $\$ 3$ billion of informal commerce, and about 30 million online shoppers in 2017. Bank Indonesia recorded the value of online trade in Indonesia; in 2017 it estimated it to be worth 85 trillion rupiah.

Online business, known as e-commerce, can be interpreted as a sale and purchase transaction through internet media (Luthfihadi \& Dewanto, 2013; OECD, 2011).With e-commerce, shopping can be done at any time from home through online shopping channels (Wang, Zhang, Ye, \& Nguyen, 2005). In addition, online transactions can cut through distribution channels, save time and costs, and reduce the transaction constraints experienced when shopping traditionally. By shopping online, consumers outside of Java can save 11 to $25 \%$ compared to traditional retail methods, while consumers on Java can save 4 to 14\% (Das et al., 2018; Tsao, Hsieh, \& Lin, 2016).

Online shopping systems are expected to make it easier for individuals to obtain the items they desire. However, most of the online shopping actors live in urban areas. With Indonesia's demographic and geographic size, there is a need for updated data and information to accurately identify potential consumers.

Many researchers conduct research related to the factors that affect individuals when shopping online in Indonesia. However, the results of those studies show variations in their conclusions. Hasyyati (2017) used Susenas 2015 data, and found that individuals who have the opportunity to shop online are women, have a low level of education, are aged between 25 to64 years old, and work in the service sector. Yusmita et al. (2012) found that in Aceh (a province in Indonesia) women and educated consumers dominate the online shopping. However, Lubis (2018)showed that in Medan (a city), males and people with a high income dominate. Age and education factors do not significantly influence online shopping decisions. The variation in the results above indicates that online business developments between the regions are not uniform, and consumer behavior varies (Beckers, Cárdenas, \& Verhetsel, 2018; Das et al., 2018).

International evidence also confirms such variety, either in America (Bellman, Lohse, \& Johnson, 1999; Donthu \& Garcia, 1999; Li, Kuo, \& Rusell, 2006; Owens \& Sarov, 2010; Swinyard \& Smith, 2003; Yang \& Lester, 2005), in India (Reddy \& Srinivas, 2015; Richa, 2012), in Hong Kong and Taiwan (Chiu, Lin, \& Tang, 2005; Sin \& Tse, 2002), and other regions (Beckers et al., 2018; Bigné, Ruiz, \& Sanz, 
2005; Clarke, Thompson, \& Birkin, 2015; Farag, Weltevreden, van Rietbergen, Dijst, \& van Oort, 2006; Mahmood, Bagchi, \& Ford, 2004; Rezai, Mohamed, Shamsudin, \& Zahran, 2013; Zhou, Dai, \& Zhang, 2007). In general, the existing literature investigates online shopping from the perspective of management and marketing studies. However, this study reviews online shopping behavior from the perspective of economic development studies, especially related to the development of information technology and the digital economy.

Due to large variations in the key factors for developing online shopping, we conducted this study to update the research into online shopping behavior. For the context of Indonesia's emerging markets, researchers must update their understanding of the dynamics of the development of online shopping behavior outside Jakarta. Since Statistics Indonesia has included more detailed questions regarding internet usage starting from Susenas 2017, it is possible to satisfy the need to update the dynamics of online shopping. We organized this paper as follows: a review of the relevant literature in Section 2.The data and research methods used will be described in Section 3 . Section 4 presents the results of the analysis and discussion, and the conclusions are in Section 5.

\section{LITERATURE REVIEW}

Theoretically, an individual consumes a product with the aim of maximizing its utility, but within his or her budget restrictions. Therefore, price and income are important factors. With the internet and a higher level of technological knowledge, one has a higher possibility of obtaining cheaper prices (Mahmood et al., 2004). In addition to price, cultural, social, personal, and psychological factors also influence the consumption decision (Kotler \& Amstrong, 2007, 131). According to Hasslinger et al. (2007), the behavior of consumers shopping online should accord with their individual characteristics, as well as the factors that influence the behavior of consumers in general. Therefore, consumers 'behavior when online shopping is also an ongoing process involving meeting the needs of buyers by selecting, buying, and using products or services (Blackwell et al., 2006). Socio demographics are an important driver of groceries e-commerce usage and channel choice (Hood et al., 2020).

Research conducted by Chiu et al.(2005) in Taiwan on 376 Chunghwa Telecom customers showed that men and women have similarities relating to their reason for online shopping. If men are more aware of the safety of online shopping, women are more concerned about the convenience of shopping. Gender significantly influences online shopping behavior or decisions. In India, women are 1.57 times more likely to shop online than men (Richa, 2012). Women in general are more likely than men to decide to shop online (Hasyyati, 2017; Hood et al., 2020; Reddy \& Srinivas, 2015; Yusmita, Nik, et al., 2012; Zhou et al., 2007). Punj (2015) found that age and gender were related to the willingness to pay for online shopping. However Lubis (2018), found that out of 200 respondents in the city of Medan, North Sumatra, men had a greater tendency to shop online. Similar results were also shown in the research conducted by Beckers et al (2018) in Belgium; Clarke et al. (2015)in the United Kingdom; Owens \& Sarov (2010)in America; Valarezo et al. (2018), Bigné et al.(2005)in Spain; and Sin \& Tse (2002)in Hong Kong.

The next factor is age. Online shoppers in America tend to be younger (Swinyard \& Smith, 2003). Zhou et al. (2007) suggested that internet users are generally middle-aged (Monsuwé et al., 2004; Smith \& Rupp, 2003). In Hong Kong, those aged between 21 and 30 tend to shop 
online (Sin \& Tse, 2002). In Indonesia, those aged 25 to 64 years old dominate (Hasyyati, 2017), while those aged 25 to 44 years old in Britain dominate (Hood et al., 2020), and someone in their 30s has the greatest tendency to shop online in Belgium (Beckers et al., 2018), while those between the ages of 14 to 24 years old form the majority of shoppers in Spain (Bigné et al., 2005). However, Donthu \& Garcia (1999), in a small sample study (200) in India, showed it was the elderly who shopped online.

The level of education is not very influential in online purchasing decisions. This is because online shopping is easy (Zhou et al., 2007); whereas according to Valarezo et al. (2018), Rezai et al. (2013), and Li et al., (2006)the level of education significantly influences online purchasing decisions due to the complicated information they may face online (Beckers et al., 2018; Bellman et al., 1999; Owens \& Sarov, 2010; Sin \& Tse, 2002; Swinyard \& Smith, 2003; Yusmita, Nik, et al., 2012). Likewise, Hasyyati's (2017)research in Indonesia showed that education had a negative effect on individuals shopping online. However, she found those who graduate from college have a higher tendency to shop online, than those with a lower education.

Monsuwé et al. (2004) concluded that income had an important role in online buying behavior. In general, people with higher incomes are more likely to shop online (Beckers et al., 2018; Bellman et al., 1999; Clarke et al., 2015; Lubis, 2018; Owens \& Sarov, 2010; Rezai et al., 2013). Lohse et al. (2000) explained that household income (social class, Smith \& Rupp 2003) has a positive effect on online shopping because with a high income, the household members will have more opportunities to access computers, the internet, education, and more purchasing power. Even though in India income does not significantly influence online shopping
(Richa, 2012), families with two household members are more likely to buy online than those who have more than two household members (Reddy \& Srinivas, 2015; Richa, 2012).

An online application in a smartphone is a medium used to do online shopping according to research byLubis (2018). But, Yang \& Lester (2005) and Owens \& Sarov (2010) show that individuals use computers to shop online. It is believed that the growing use of smartphones may come to dominate online shopping activities.

In general, those who live in urban areas or big cities do more online shopping than those in rural areas (Beckers et al., 2018; Bigné et al., 2005; Clarke et al., 2015; Farag et al., 2006). But, with better internet connections in rural areas, and other factors, opportunities for the people living there to shop online may soon occur. Various other demographic, socioeconomic, and spatial factors that determine the characteristics of individual behavior in shopping online are dynamic. In a growing nation like Indonesia, the latest developments regarding online shopping behavior need to be updated to detect the above changes and dynamics.

\section{DATA AND METHOD OF ANALYSIS}

This study used data from The National SocioEconomic Survey 2017 (Susenas 2017) conducted by Statistics Indonesia (BPS). The unit of analysis was the number of household members who are internet users. An internet user is someone who takes the time to access the internet, with the aim of benefiting or enjoying its facilities, despite not having the ability to open and close (login and log out) the internet (BPS, 2017c). Susenas 2017 consists of 300,000 sample households. The Information on internet users defines them as individuals aged over 5 
years old (285,920 individuals as the sample). In this study, we categorized internet users as being over 10 years old, because employment information is only available on individuals over 10 years old. After determining the analysis unit's selection and data cleaning, 281,185 internet users were used.

The dependent variable in this study is online shopping. BPS (2017) defined online shopping as the activity of ordering and buying various goods/services via the internet, both using online and offline payment methods, with cancelled or incomplete bookings being excluded (BPS, 2017c). This variable is obtained from question R707.e.The independent variables in this study are the demographic, socioeconomic, and spatial factors. The demographic factors include gender, age, and marital status, position in the household, and the number of household members. The socio-economic factors include education, main activities, and income (which is proxied by household expense per capita), and the media system used to access the internet. Household expense per capita is transformed into a natural $\log$ (ln) intended to reduce variance. The spatial factor in this study is the area of residence.

In this study, a binary logistic regression analysis was used to determine the effect of the demographic, socio-economic, and spatial factors on the individual's preference to shop online. The model used in this study was based on the model used by Beckers et al. (2018), Hasyyati (2017), and Lubis (2018). Mathematically, the equation is explained in model 3.1:

$$
\ln \left(\frac{p_{i}}{1-p_{i}}\right)=X \beta+Y \alpha+S \gamma+\varepsilon(1)
$$

The subscript iin Equation 3.1 show each different individual. $X$ denotes a vector for the demographic factors, $Y$ denotes a vector for the socio-economic factors and $S$ denotes a vector for the spatial factors, and $\varepsilon$ is an error term.
We added dummy variables for the level of education possessed by the respondents, namely elementary, junior high, high school, diploma, undergraduate, and postgraduate. The employment sector variables are the primary, secondary, and tertiary sectors. Based on the Indonesian Standard Industrial Classification (Klasifikasi Baku Lapangan Usaha Indonesia or "KBLI"),the primary sector consistsof Section A (agriculture, forestry, and fishery) and Section B (mining and quarrying). The secondary sector consists of Section C (manufacturing), Section D (electricity, gas, steam and air conditioning supply), Section E (water supply; sewerage, waste management and remediation activities), and Section $\mathrm{F}$ (construction). The tertiary sector consist of Section G(wholesale and retail trade; the repair of motor vehicles and motorcycles), Section $\mathrm{H}$ (transportation and storage), Section I (accommodation and food service activities), Section J (information and communication), Section $\mathrm{K}$ (financial and insurance activities), Section $\mathrm{L}$ (real estate activities), Section M (professional, scientific and technical activities),Section $\mathrm{N}$ (administrative and support service activities), Section $O$ (public administration and defence; compulsory social security), Section $\mathrm{P}$ (education), Section Q (human health and social work activities), Section R (arts, entertainment and recreation), Section $\mathrm{S}$ (other service activities), Section $\mathrm{T}$ (activities of households as employers; undifferentiated goods- and servicesproducing activities of households for own use), and Section U (activities of extraterritorial organizations and bodies (BPS, 2015)

Whether an individual is still in school, attending college, or taking care of their household, he or she is denoted by the variable in school, college, or household worker. In our study, we use control variables respectively as follows: (1) variable for small family size (1=if the number of household members is between 1 
and 4 and $0=$ more than four household members); (2) variable to differentiate residential areas as urban (1) or rural (0); (3) economic factors such as per capita income (Income) are also included in this model. Finally, the use of media variables for accessing the internet, such as laptops or smartphones is also taken into account.

We estimate the model by using different aggregated data, the national model, regions 1 to 4 , and islands. The four regions are based on the portion of online shopping according to Das et al. (2018, 33). Region 1 covers the Greater Jakarta area (Jakarta, Bogor, Tangerang, Bekasi, and Depok) (Das et al., 2018; and Bappenas, 2015). Region 2 includes the Greater Bandung area (Das et al., 2018; and BPS, 2017b), Kedungsepur (Kendal, Demak, Semarang Regency, Semarang City, Salatiga, and Grobogan/Purwodadi) (Bappenas, 2015; Hudalah et al., 2013), and Gerbangkertosusila (Gresik, Bangkalan, Mojokerto, Surabaya, Sidoarjo, and Lamongan) (BPS, 2017b; Bappenas, 2015). Region 3 covers 100 districts/cities with the largest population in Indonesia (BPS, 2018). Region 4 covers 382 other regencies/cities (BPS, 2018).Actually, Statistics Indonesia categorizes Indonesia into nine islands(BPS, 2018), and in this study, we recategorized the island model by dividing it into seven islands: Sumatra (including Kepulauan Bangka Belitung and Kepulauan Riau), Java, Nusa Tenggara (Bali, Nusa Tenggara Barat, and Nusa Tenggara Timur), Kalimantan, Sulawesi, Maluku, and Papua. This estimation strategy is meant to identify which factors are important in different regions/islands to capture the dynamic development of online shopping in Indonesia.

\section{RESULTS AND DISCUSSION}

Table 4.1 shows that all the independent variables in the national model simultaneously influence the dependent variable. The correctly classified value shows that overall the logit regression model had a suitability level of 92.4\%in predicting whether individuals would buy or not buy products online. The model was also free from multicollinearity problems, having a variance inflation factor (VIF) value 4.3 (under 10).

For the regional models, Table 4.1 shows that all the models were significant and could be tested in all categories. They were free of multicollinearity problems as the average value of VIF in each model was still below 10. The suitability level of the models was quite high, as the correctly classified values ranged from 87.88 to $95.18 \%$. From the pseudo $\mathrm{R}^{2}$ value, it had a low value ranging from 14 to $19.7 \%$, which indicated that predicting the behavior was still difficult as there was a lot of variation in online shopping decisions.

Based on the results in Appendix 1 and Appendix 2, for the national model, higher income (OR=2.355); female $\quad(\mathrm{OR}=1.997)$; accessing the internet using a smartphone (OR=2.698) or laptop (OR=2.037); household position as the household head $(\mathrm{OR}=1.478)$ and wife/husband $(\mathrm{OR}=2.210)$; age 19 years $(\mathrm{OR}=2.113)$, age 19 to 24 years ( $\mathrm{OR}=3.116)$, age 25 to 30 years $(\mathrm{OR}=3.497)$, age 31 to 36 $(\mathrm{OR}=3.123)$, age 37 to 42 years $(\mathrm{OR}=2.605)$, age 43 to $48(\mathrm{OR}=1.757)$, age 49 to 54 years ( $\mathrm{OR}=1.182$ ); being a student in secondary school (OR=1.532), high school (OR=1.738), diploma ( $\mathrm{OR}=2.105)$, undergraduate $(\mathrm{OR}=1.913)$, and graduate ( $\mathrm{OR}=1.589$ ); main occupation being in the secondary sector $(\mathrm{OR}=1.359)$, tertiary sector $(\mathrm{OR}=1.548)$, lecturing $(\mathrm{OR}=1.228)$, and taking care of the household ( $\mathrm{OR}=1.314)$; and living in an urban area $(\mathrm{OR}=1.573)$ are all associated with a higher probability of shopping online. 
Table 4.1 Statistical characteristics of the model

\begin{tabular}{lccccc}
\hline \multicolumn{1}{c}{ Models } & Number of Sample & LR Statistic & Pseudo $\boldsymbol{R}^{2}$ & Correctly classified (\%) $^{\text {Mean VIF }}$ \\
\hline National & 281,185 & $24,727.53^{* * *}$ & 0.163 & 92.40 & 4.30 \\
Regions: & & & & & \\
1. Region 1 & 23,314 & $2,529.03^{* * *}$ & 0.142 & 87.88 & 3.54 \\
2. Region 2 & 19,323 & $1,773.63^{* * *}$ & 0.145 & 90.87 & 3.82 \\
3. Region 3 & 76,754 & $5,960.01^{* * *}$ & 0.154 & 93.17 & 4.36 \\
4. Region 4 & 161,794 & $13,943.23^{* * *}$ & 0.167 & 92.89 & 4.65 \\
Islands: & & & & & \\
1. Sumatra & 76,653 & $6,783.35^{* * *}$ & 0.177 & 93.23 & 4.92 \\
2. Java & 106,088 & $9,344.04^{* * *}$ & 0.154 & 91.73 & 3.90 \\
3. Nusa Tenggara & 18,103 & $1,401.67^{* * *}$ & 0.146 & 92.96 & 4.80 \\
4. Kalimantan & 28,984 & $3,186.35^{* * *}$ & 0.174 & 90.69 & 4.77 \\
5. Sulawesi & 36,794 & $3,443.05^{* * *}$ & 0.174 & 92.63 & 4.55 \\
6. Maluku & 6,220 & $534.54^{* * *}$ & 0.197 & 95.18 & 5.06 \\
7. Papua & 8,343 & $532.64^{* * *}$ & 0.140 & 94.91 & 4.54 \\
\hline
\end{tabular}

Notes : Significance levels: ***1\%, **5\%, *10\%

Source : BPS (Susenas 2017, estimated)

Gender differences in this study affect different trends in online shopping. Women have a greater tendency to shop online than men in all the categories for the regions. The odds ratio value of 1.997 shows that the tendency for women to shop online is 1.99 times greater than that for men. These findings are in line with the research conducted by Hasyyati (2017); Hood et al., (2020); Reddy \& Srinivas (2015); Richa (2012); Yusmita et al., (2012); and Zhou et al., (2007) where the tendency for women to shop online is higher than for men. Although internet users are mostly men, women have a higher preference for shopping online.

The next discussion is the income variable. For this variable we used the household expenditure approach (from BPS). Using households' expenditure to predict Income was captured by all the research models. The statistical results showed that the higher the income was, the more individuals would shop online. The odds ratio value of 2.355 indicates that the tendency of individuals with a certain income level to shop online is 2.35 times greater than for people in the income level below. These findings are in line with research conducted by Donthu \& Garcia
(1999); Swinyard \& Smith (2003); Owens \& Sarov (2010); Dahiya (2012); Rezai et al. (2013); Clarke et al.(2015); Lubis (2018); and Beckers et al. (2018), who stated that the higher the income, the more likely the individual was to shop online.

The position of individuals in the household has a significant effect on online shopping. This finding is in line with the findings of Owens \& Sarov (2010) and Hasyyati (2017), which showed that the role of the head of the household in purchasing products, both goods and services, is important. In the national model, if the individual is a child, the family will have a lesser tendency to shop online. The tendency to shop online is greatest if the individual's status is the household head, either the wife or husband. This can be seen in the odds ratio value of 2.210, which means that the head of the household's tendency to shop online is 2.21 times greater than that of people in other categories.

Another independent variable that influences the tendency to shop online is the type of media. Those who access the internet with a cell phone have a greater tendency to shop online than those using other means of access in all the model 
categories. The odds ratio value for the mobile phone category is 2.698 , which means that the tendency of individuals to use mobile phones to access the internet and shop online is 2.69 times greater than for those using other methods. This shows that mobile phones are a significant factor in influencing consumers 'behavior to shop online. This finding is in line with the findings of Lubis (2018).

According to Beckers et al. (2018), the equal distribution of infrastructure will minimize the influence of geographic factors on consumer behavior in shopping online. An improved network quality will increase the number of individuals in rural areas who shop online (Clarke et al., 2015). Thus, from the odds ratio value on the island category model, the gap in the use of cell phones and PCs / laptops from the lowest to the highest is Java, Sulawesi, Sumatra, Bali and Nusa Tenggara, Kalimantan, Maluku, and Papua, respectively.

Another parameter that influences individuals to shop online is their age. In general, the age variable significantly influences individuals to shop online, which is in line with the results of the research by Bigné et al. (2005); Zhou et al. (2007); Dahiya (2012); and Rezai et al. (2013). However, the effect of age on individuals shopping online is not captured in Papua. Individuals aged 25 to 30 years of age have a higher tendency than those in other age categories in all the regional and island categories, except for Region 2 and the Maluku islands; where there is a higher tendency to shop online aged between 31 to 36 years old. In the national model, the tendency of the 25 to 30 year olds to shop online is seen in the odds ratio of 3.497 , which means the tendency of 25 to 30 year olds to shop online is 3.49 times that of the other age groups. Other age groups that have a relatively high tendency to shop online are the 19 to 24 year olds and the 31 to 36 year olds. These findings are in line with research by Sin \& Tse (2002); Swinyard \& Smith (2003); Clarke et al. (2015); Hasyyati (2017); and Beckers et al. (2018).

Different levels of education also affect the tendency of someone to shop online. These findings are in line with research by $\mathrm{Li}$ et al. (2006); Zhou et al. (2007) and Rezai et al. (2013) who stated that age is a significant factor in influencing individuals to shop online. However, the effect of the education level variables on individuals shopping online is not captured in the Maluku islands.

It can be seen that the greatest tendency for individuals to shop online is captured in all the models if the individual has a diploma and/or bachelor's degree (tertiary education). This finding is in line with the results of Beckers et al. (2018); Owens \& Sarov (2010); Sin \& Tse (2002); Swinyard \& Smith (2003); and Yusmita et al. (2012), that online shoppers are usually highly educated. The effect of education on individuals shopping online shows a hyperbolic pattern (at the beginning it is low, subsequently high, and then decreases). According to the level of individual education from low to high levels of education, there was an increase in the tendency to shop online in general, the peak was at the level of having a diploma education (except on the island of Papua, which was at the junior high school level), after that the tendency to shop online declined. In the national model, looking at the odds ratio value of 2.1, it can be interpreted that the tendency of individuals with a diploma education to shop online is 2.1 times that of people with other levels of education.

The area where individuals live also influences the tendency of individuals to shop online. Someone who lives in an urban area is more likely to shop online than an individual living in a rural area. At the national level, individuals who live in urban areas are 1.57 
times more likely to shop online than those who live in rural areas. These results are in line with the findings in the research of Beckers et al. (2018); Clarke et al. (2015) and Farag et al. (2006), where the phenomenon of online shopping is still an urban phenomenon, especially in the city centers. The fact is that in developing countries, people with the high economic class and level of education are still concentrated in urban areas. This is one of the factors driving demand disparity (Beckers et al., 2018).

In the area category according to islands/ archipelago, the influence of an individual's residential area variable is not captured in the Maluku islands region. This shows that each region has different characteristics. In general, the tendency to shop online when individuals reside in urban areas outside Java is greater than when compared to Java (especially in Region 2).

In general, based on the national model, the main occupation has a significant effect on an individual's tendency to shop online. Those who are working in the secondary sector have the highest probability to shop online; next are those employed in the tertiary sector, lecturing, and taking care of their household. Students are less likely to shop online. Individuals who work in the tertiary sector are 1.54 times more likely to shop online compared to individuals in the other main sectors. This finding reconfirm that of Hasyyati (2017): individuals who work in the service sector (tertiary employment sector) had the highest probability of shopping online.

The individual job factor varies greatly for the different regional or island categories. College students have the highest tendency to shop online, but not in all the regions; in regions 2,3 and 4, as well as Sumatra and Java, students dominated the online shopping. Overall, the greatest tendency to shop online is by those who work in the tertiary and secondary sectors, housewives, and then those working in the primary sector.

Being a student means the person has a higher tendency to shop online. From Region 4 to Region 2, the parameter decreases. When people's age approaches 19 years old, the tendency to shop online increases; but these people maybe students.

The number of household members does not significantly influence an individual's tendency to shop online. This result is in line with the findings of Clarke et al. (2015). However, when tested on the regional and island categories, a negative effect was seen. If the family's size is small (less than four family members) the tendency not to shop online increased in Region 3 , as well as the categories of Java and the Maluku islands.

Marital status is also seen as one of the variables that influence individuals to shop online. In general, based on the national model, the tendency of individuals who are unmarried to shop online is 0.9 times greater than individuals with another status. When marital status variables are tested in a regional category, most indicate that there is no influence of marital status on the tendency of individuals to shop online. This condition is in line with research by Dahiya (2012), Reddy \& Srinivas (2015), and Hasyyati (2017). The negative influence of the marital status variables with the category of unmarried was caught only in four regional categories, namely: Region 4, Sumatra, Sulawesi, and the Maluku islands. This shows the amount of variation in the influence of the marital status variables on the likelihood of individuals to shop online, and that the geographical or spatial factors of an area/region have different characteristics.

Based on the description of the parameters of each independent variable above, individuals with a higher tendency to shop online in all categories of the regions have the following 
characteristics, namely they are female, have a spouse who is head of the household, they have a high income, use a cell phone to access the internet, live in urban areas (except the Maluku islands), graduated from university, especially with a diploma (except Papua, which was junior high school), are aged between 25 to 30 years old (except Region 2 and the Maluku islands, ages 31 to 36 years), and work in the tertiary sector (except Papua, working in the primary sector). These varied estimates coefficients across the regions and islands indicate the dynamics of online shopping behavior. Age, family size, spouse as the head of the household and the location will change the determinants of online shopping behavior.

Figure 1 shows the dynamics of the shifting of the main characteristics from various regions (Region 4 to Region 1). When the portion of online shopping is higher in the region (Region 1), that implies the characteristics of the consumers will be similar. The higher the portion of online shopping in a region, the concentration of the influence of the main characteristics of individuals on the tendency to shop online according to demographic, socioeconomic, education, and spatial factors will increasingly fade.

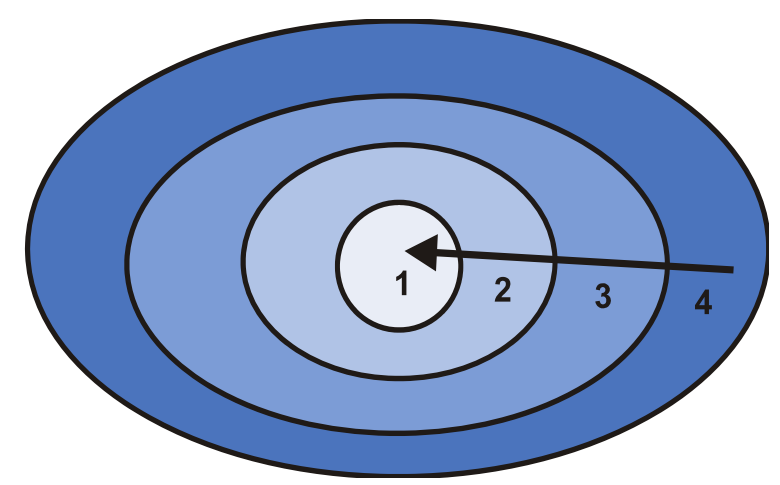

Figure 1. Illustrate the thickness influence of individual characteristics to shop online at different regions.

The shifts in the pattern of the main characteristics of online buyers in Circle 4 which tend to be thick and then fades towards Circle 1 with the following picture:

1. It grows from individuals with high incomes to individuals with lower incomes.

2. From female to no gap between genders.

3. From using a mobile phone to access the internet to other means of access when mobile user penetration (smartphone) is fairly optimum and the disparity in the quality of the infrastructure between regions is relatively low.

4. From individuals with the status as the spouse of the head of the household (wife/husband) to the head of the household and other household members.

5. From the age group between 25 to 30 years old to the younger age group (age groups less than 19 years and 19 to 24 years).

6. From individuals who live in areas with advanced economic conditions (metropolitan areas) on the island of Java to advanced cities outside of Java and then to rural areas.

7. From individuals who graduated from college (diploma and bachelor) to other levels of education, but also related to their knowledge of internet usage.

8. From individuals who work in the tertiary sector to individuals who work in other sectors, housewives, lectures, and other jobs.

The development of online shopping patterns in Indonesia is still influenced by the characteristics of people's residential areas (urban vs. rural). In addition, the method of accessing the internet is also part of the spatial aspects. The use of cell phones gives a greater tendency for individuals to shop online compared to PCs/laptops. This indicates that there is a need for flexibility in connectivity, given the more portable nature of mobile phones. That is, the internet network's coverage needs to be broad so that users can connect to the internet anywhere. 
Based on the influence of the individual factors for online shopping behavior and the patterns of online shopping behavior's development, the factors that can be used as indicators of e-commerce's development by region include: income (household's expenditure per capita), internet access, age groups, urban/rural classification, and education level. The formation of an area's socio-economic indicators is a socioeconomic condition of the household, derived from individual data. Based on the factors that affect individuals shopping online, the indicators of the potential regions for the development of ecommerce in Indonesia include those with: urban characteristics (areas with high population and density); high regional income per capita and high education levels, good penetration of the internet and mobile users and large numbers of 19 to 36 year olds.

\section{CONCLUSION}

We conclude that individuals who have a greater tendency to shop online have the following characteristics: a higher income, they are female, they access the internet using a cell phone, have the household position as the household's head, aged 25 to 30 years old, living in an urban area, working in the tertiary sector, and are college graduates. All the demographic, socio-economic, and spatial factors affect individuals 'decisions to shop online. However, influencing factors vary in each regional category. The lower the penetration of online shopping is in an area, the variation in online shopping behavior will be higher, so that only a few variables significantly influence the tendency of individuals to shop online. The higher the portion of online shopping there is in a region, the density of the influence of individual characteristics on the tendency to shop online, according to the demographic, socio-economic, and spatial factors, will decrease. There are four main factors that significantly influence individuals online shopping, namely: income, gender, internet access, and household position.

In the development of the digital economy in Indonesia, it is known that the development of online shopping patterns still varies across the regions. The gap across regions decreases when the coverage and quality of the internet network increases. As younger people are potential users of online shopping, educating these people could increase the development.

Alternative indicators could also be created to make categorizing potential-commerce development areas more easy, in addition to using the population approach (as in Region 3), for example, urban characteristics (areas with a large population and density); a level of welfare as the aggregate of individual well-being and education, penetration of the internet and the number of mobile users, the proportion of the working-age group, especially in the 19 to 36 age group (can use dependency ratio). Individual factors can be used as alternative indicators for the creation of e-commerce development maps in Indonesia, which will lead to the formation of a national logistics system, in order to improve efficiency and competitiveness.

In this study, there are several limitations. First, we conducted the study over a single year not over a number of years, which may provide less evidence for predicting the shift in online shopping patterns in Indonesia. Second, we proxied income by household expenditure per capita, internet users were aged 10 years and over, and it was assumed that the prices of products, goods and services other than those sold via online shopping did not change (ceteris paribus).In addition, this research only provides a description of the potential development of ecommerce in terms of its potential consumers' characteristics. Moreover, this research did not examine the market segmentation related to the 
category of goods/services, the consumption level, the market place used for online shopping, and the frequency of shopping.

Further research is expected to explore other factors driving consumers to shop online, using the latest panel data for robust findings in evaluating the impact of online shopping patterns, which should not just cover a single year. In addition, there is a need to find methods to measure the impact's evaluation, such as Propensity Scaling, Difference in Difference, and others, so the findings can be used as a support for government policy toward digital economic development, which is in line with increasing economic growth and reducing inequality. Finally, the administration of data and information related to the development of ecommerce can be improved by conducting special surveys and the use of big data. The data and information can be used as material for the evaluation of national and regional planning, especially when related to digital economic developments.

\section{REFERENCE}

APJII. (2017). Penetrasi dan perilaku pengguna internet Indonesia. Retrieved August 26, 2018, from Penetrasi dan perilaku pengguna internet Indonesia website:

https://www.apjii.or.id/content/read/39/342/

Hasil-Survei-Penetrasi-dan-Perilaku-

Pengguna-Internet-Indonesia-2017

Badan Pusat Statistik. (2015). Klasifikasi Baku Lapangan Usaha Indonesia 2015. Jakarta: Badan Pusat Statistik.

Badan Pusat Statistik. (2017a). Hasil Pendaftaran Usaha/Perusahaan Sensus Ekonomi 2016 Indonesia. Jakarta: BPS-Statistics Indonesia.

Badan Pusat Statistik. (2017b). Pedoman Pengawasan Survei Komuter Bandung Raya dan Gerbangkertosusila 2017. Jakarta: Badan Pusat Statistik.
Badan Pusat Statistik. (2017c). Statistik Kesejahteraan Rakyat 2017. Jakarta: Badan Pusat Statistik/BPS-Statistics Indonesia.

Badan Pusat Statistik. (2018). Statistik Indonesia 2018. Jakarta: Badan Pusat Statistik.

Beckers, J., Cárdenas, I., \& Verhetsel, A. (2018). Identifying the geography of online shopping adoption in Belgium. Journal of Retailing and Consumer Services, 45, 33-41. https://doi.org/10.1016/j.jretconser.2018.08. 006

Bellman, S., Lohse, G. L., \& Johnson, E. J. (1999). Predictors of online buying behavior. Communications of the ACM, 42 (12), 32-38.

https://doi.org/10.1145/322796.322805

Bigne, E., Ruiz, C., \& Sanz, S. (2005). The impact of internet user shopping patterns and demographics on consumer mobile buying behaviour. Journal of Electronic Commerce Research, 6 (3), 193. https://doi.org/10.1016/0025326x(74)90172-6

Blackwell, R. D., Miniard, P. W., \& Engel, J. F. (2006). Consumer behavior, 10th edn, Thomson South-Western, Boston. Cochran, WG (1977). Sampling techniques. New York: John Wiley \& Sons. Comer and TA Wikle (2008), Worldwide diffusion of the cellular telephone, (1995-2005). The Professional Geographer, 60(2), 252-269.

Chiu, Y. B., Lin, C. P., \& Tang, L. L. (2005). Gender differs: assessing a model of online purchase intentions in e-tail service. International journal of service industry management.

https://doi.org/10.1108/09564230510625741

Clarke, G., Thompson, C., \& Birkin, M. (2015). The emerging geography of e-commerce in British retailing. Regional Studies, Regional Science, 2 (1), 371-391. https://doi.org/10.1080/21681376.2015.105 4420

Das, K. (2018). The digital archipelago: How online commerce is driving Indonesia's economic development. McKinsey. 
Retrieved from

www.mckinsey.com/featured-insights/asiapacific/the-digital-archipelago-how-online-

Donthu, N., \& Garcia, A. (1999). The internet shopper. Journal of advertising research, 39(3), 52-52.

Farag, S., \& Weltevreden, J. v. Rietbergen, T., Dijst, M. \& v. Oort, F.(2006). E-shopping in the Netherlands: does geography matter? Environment and Planning B: Planning and Design, 33, 59-74. https://doi.org/10.1068/b31083

Hasslinger, A., Hodzic, S., Opazo, C., Kallström, L., \& Ekelund, C. (2007). Consumer Behaviour in Online Shopping, Arbectsgemeinschaft Online-Forschung e.

Hasyyati, A. N. (2017). Demographic and socioeconomic characteristics of e-commerce users in Indonesia (No. 776). ADBI Working Paper.

Hood, N., Urquhart, R., Newing, A., \& Heppenstall, A. (2020). Sociodemographic and spatial disaggregation of e-commerce channel use in the grocery market in Great Britain. Journal of Retailing and Consumer Services, 55, 102076.

https://doi.org/10.1016/j.jretconser.2020.10 2076

Hudalah, D., Zulfahmi, F., \& Firman, T. (2013). Regional governance in decentralizing Indonesia: Learning from the success of urban-rural cooperation in metropolitan Yogyakarta. In Cleavage, connection and conflict in rural, urban and contemporary Asia (pp. 65-82). Springer, Dordrecht. https://doi.org/10.1007/978-94-007-54829_5

Kementerian Perencanaan Pembangunan Nasional/Badan Perencanaan Pembangunan Nasional. (2015). Lampiran Peraturan Presiden Nomor 2 Tahun 2015 Tentang Rencana Pembangunan Jangka Menengah Nasional 2015-2019. Jakarta: Kementerian Perencanaan Pembangunan Nasional/Badan Perencanaan Pembangunan Nasional.
Kotler, P., \& Armstrong, G. (2007). Principles of Marketing 12th Edition: Pearson Prentice Hall. Upper saddle river New Jersey.

Li, H., Kuo, C., \& Rusell, M. G. (2006). The impact of perceived channel utilities, shopping orientations, and demographics on the consumer's online buying behavior. Journal of Computer-Mediated Communication, 5 (2), 1-20.

https://doi.org/10.1111/j.1083-

6101.1999.tb00336.x

Lohse, G., Bellman, S., \& Johnson, E. J. (2000). Consumer buying behavior on the Internet: Findings from panel data. Journal of interactive Marketing, 14 (1), 15-29. https://doi.org/10.1002/(SICI)15206653(200024)14:1<15::AIDDIR2>3.0.CO;2-C

Lubis, A. N. (2018). Evaluating the customer preferences of online shopping: Demographic factors and online shop application issue. Academy of Strategic Management Journal, 17 (2), 1-13.

Luthfihadi, M., \& Dewanto, W. (2013). Technology acceptance of e-commerce in Indonesia. International Journal of Engineering Innovation and Management, 3, 918.

https://doi.org/10.1109/TCSI.2012.2215794

Mahmood, M. A., Bagchi, K., \& Ford, T. C. (2004). On-line shopping behavior: Crosscountry empirical research. International Journal of Electronic Commerce, 9(1), 9-30. https://doi.org/10.1080/10864415.2004.110 44321

Monsuwé, T. P., Dellaert, B. G., \& De Ruyter, K. (2004). What drives consumers to shop online? A literature review. International journal of service industry management. https://doi.org/10.1108/09564230410523358

Organisation for Economic Co-operation and Development. (2011). OECD guide to measuring the information society 2011. OECD.

Owens, T. R., \& Sarov, M. G. (2010). Determinants of consumer attitudes towards e- 
commerce. Issues in Political Economy, 19, 29-50.

Punj, G. (2015). The relationship between consumer characteristics and willingness to pay for general online content: Implications for content providers considering subscription-based business models. Marketing Letters, 26(2), 175-186. https://doi.org/10.1007/s11002-013-9273-y

Reddy, N. H., \& Srinivas, A. (2015). Impact of Demographic Factors of Indian Consumers on Online Shopping Behaviour. International Journal of Accounting and Business Management, 3(1), 310-317.

https://doi.org/10.24924/ijabm/2015.04/v3.i ss1/310.317

Rezai, G., Mohamed, Z., Shamsudin, M. N., \& Zahran, M. Z. (2013). Effect of consumer demographic factors on purchasing herbal products online in Malaysia. International Journal of Economics and Management Engineering, 7(8), 2380-2386.

Richa, D. (2012). Impact of demographic factors of consumers on online shopping behaviour: A study of consumers in India. International journal of engineering and management sciences, 3(1), 43-52.

https://doi.org/10.24924/ijabm/2015.04/v3.i ss1/310.317

Sin, L., \& Tse, A. (2002). Profiling internet shoppers in Hong Kong: demographic, psychographic, attitudinal and experiential factors. Journal of International Consumer Marketing, 15(1), 7-29. https://doi.org/10.1300/J046v15n01

Smith, A. D., \& Rupp, W. T. (2003). Strategic online customer decision making: leveraging the transformational power of the Internet. Online information review. https://doi.org/10.1108/14684520310510055

Swinyard, W. R., \& Smith, S. M. (2003). Why people (don't) shop online: A lifestyle study of the internet consumer. Psychology \& marketing, 20(7), 567-597.

https://doi.org/10.1002/mar.10087

Tsao, W. C., Hsieh, M. T., \& Lin, T. M. (2016). Intensifying online loyalty! The power of website quality and the perceived value of consumer/seller relationship. Industrial Management \& Data Systems.

https://doi.org/10.1108/IMDS-07-20150293

Valarezo, Á., Pérez-Amaral, T., Garín-Muñoz, T., García, I. H., \& López, R. (2018). Drivers and barriers to cross-border ecommerce: Evidence from Spanish individual behavior. Telecommunications Policy, 42(6), 464-473.

https://doi.org/10.1016/j.telpol.2018.03.006

Wang, C. L., Zhang, Y., Ye, L. R., \& Nguyen, D. D. (2005). Subscription to fee-based online services: What makes consumer pay for online content?. Journal of Electronic Commerce Research, 6(4), 304.

Yang, B., \& Lester, D. (2005). Gender differences in e-commerce. Applied Economics, 37(18), 2077-2089. https://doi.org/10.1080/00036840500293292

Yusmita, F. (2012). Nik Kamariah Nik Mat, Mulyagus Usman Muhammad, Yuhainis Mohd Yusoff, Fitrisal azhar, Saeed Behjati (2012). Determinants of Online Purchasing Behavior in Nanggroe Aceh Darussalam. American Journal of Economics June, 153157.https://doi.org/10.5923/j.economics.201 20001.34

Zhou, L., Dai, L., \& Zhang, D. (2007). Online shopping acceptance model-A critical survey of consumer factors in online shopping. Journal of Electronic commerce research, 8(1). https://doi.org/10.1086/209376. 


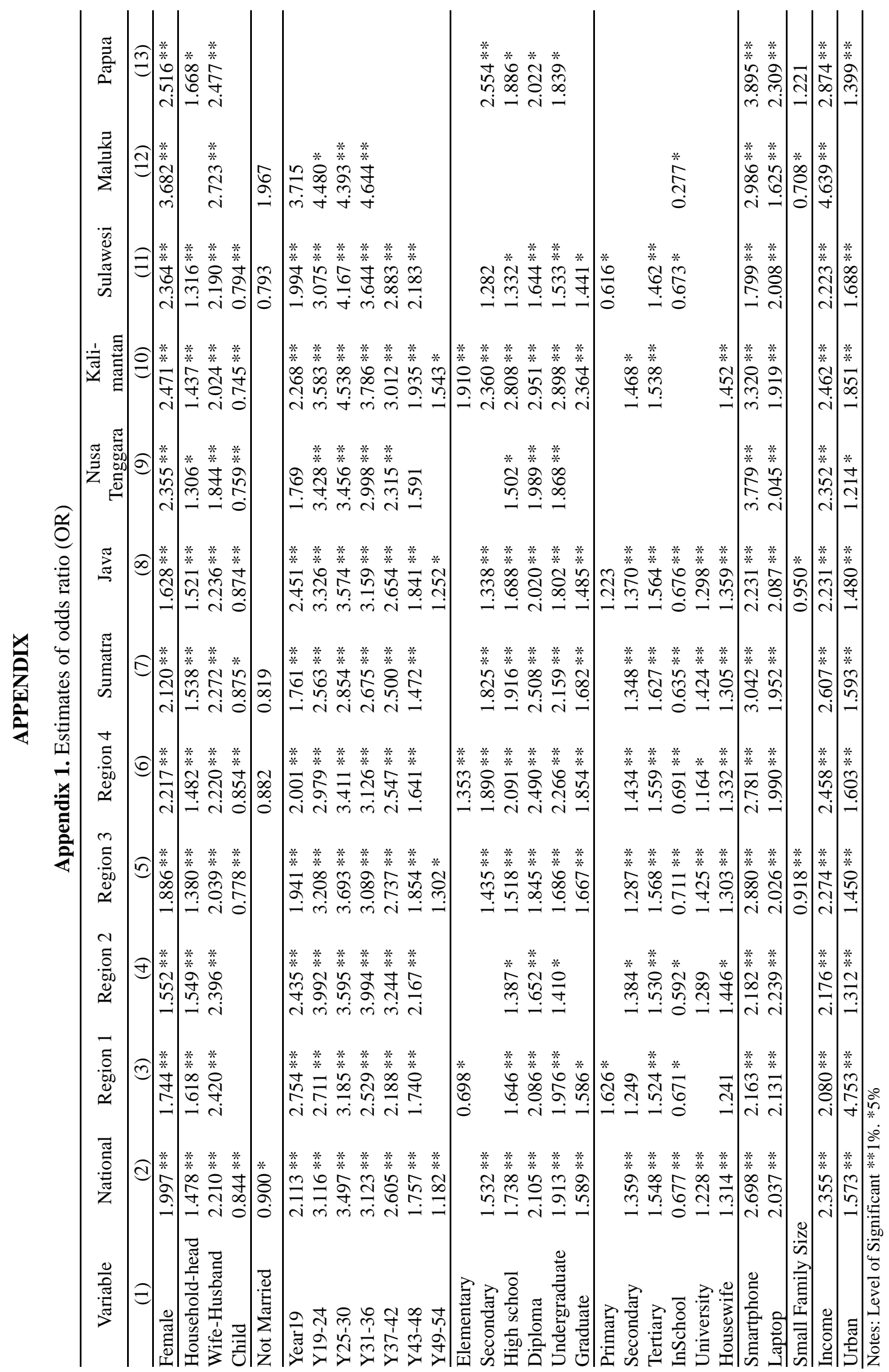




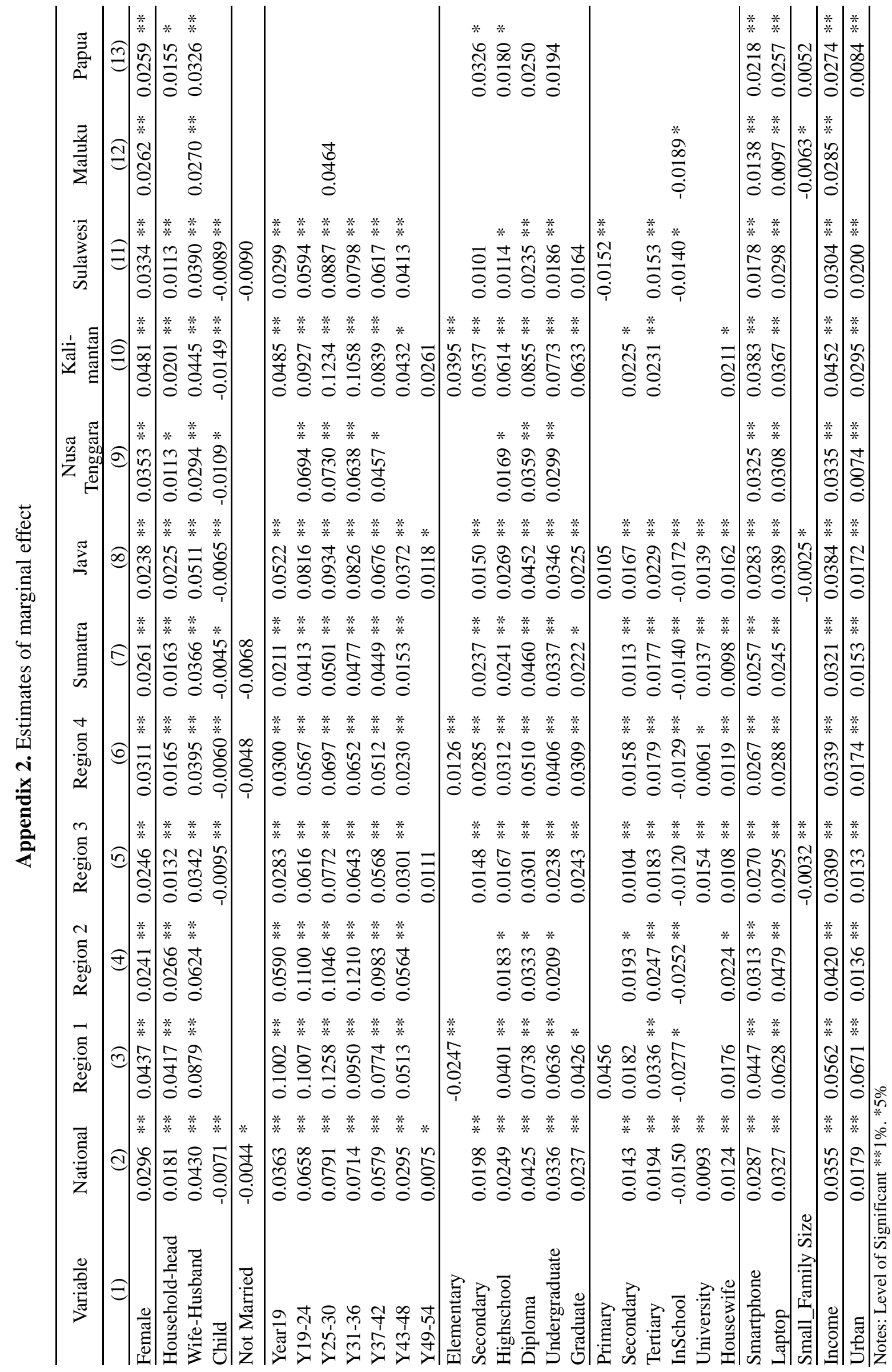

